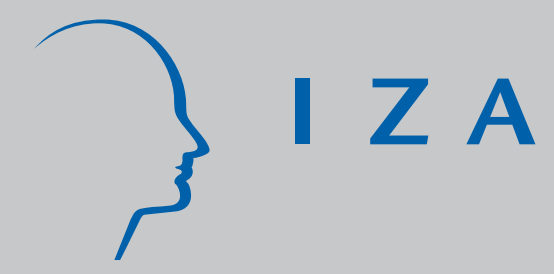

IZADP No. 3569

Why Should State Government Invest in College

Education? An Equilibrium Approach for the US in 2000

Michael P. Shields

J une 2008 


\title{
Why Should State Government Invest in College Education? An Equilibrium Approach for the US in $\mathbf{2 0 0 0}$
}

\author{
Michael P. Shields \\ Central Michigan University \\ and IZA
}

Discussion Paper No. 3569

June 2008

IZA

P.O. Box 7240

53072 Bonn

Germany

Phone: +49-228-3894-0

Fax: +49-228-3894-180

E-mail: iza@iza.org

\begin{abstract}
Any opinions expressed here are those of the author(s) and not those of IZA. Research published in this series may include views on policy, but the institute itself takes no institutional policy positions.

The Institute for the Study of Labor (IZA) in Bonn is a local and virtual international research center and a place of communication between science, politics and business. IZA is an independent nonprofit organization supported by Deutsche Post World Net. The center is associated with the University of Bonn and offers a stimulating research environment through its international network, workshops and conferences, data service, project support, research visits and doctoral program. IZA engages in (i) original and internationally competitive research in all fields of labor economics, (ii) development of policy concepts, and (iii) dissemination of research results and concepts to the interested public.
\end{abstract}

IZA Discussion Papers often represent preliminary work and are circulated to encourage discussion. Citation of such a paper should account for its provisional character. A revised version may be available directly from the author. 


\begin{abstract}

\section{Why Should State Government Invest in College Education?} An Equilibrium Approach for the US in 2000*

This paper is a preliminary look at the benefits to states in the US of subsidizing college education. The benefits studies are the external benefits of college education on the earnings of both college graduates and those who have not graduated from college. In completing a college education individuals earn more. In addition, if there are positive external benefits others will also earn more because the average level of college graduates in the state has risen. This study confirms the existence of these positive externalities for the US in 2000 in estimates using the Current Population Survey. Furthermore, these external benefits are large enough that if confirmed in more complete studies would suggest that states invest too little in college education.
\end{abstract}

JEL Classification: J2, J24, H52

Keywords: $\quad$ human capital, externalities, higher education

Corresponding author:

Michael P. Shields

Department of Economics

Central Michigan University

Mt. Pleasant, MI 48859

USA

E-mail: Michael.P.Shields@cmich.edu

\footnotetext{
* I would like to thank participants in the brown bag lunch seminar in the economics program at the RSSS at Australian National University for helpful comments.
} 


\section{Why Should State Government Invest in College Education? An Equilibrium Approach}

College education is highly subsidized by state government in the US. There are numerous justifications for this subsidization of which three will be mentioned here. First, subsidization increases the access to college education and hence increases the possibility for upward economic mobility. Higher economic mobility could be valued in part as a social goal for its own sake and partly because it leads to greater effort and more innovative behavior. Second, universities might directly create consumption and production externalities to firms or people located near the university. Hence, local communities might lobby for more state support. Third, a college education might indirectly create production externalities due to a higher average level of education of the labor force. This third possibility has been central to models of economic growth. In this paper we will consider evidence for this third possible source of externalities. A model of these statewide externalities based on the growth model developed by Lucas (1988) will be developed and tested. In the first section, a model of externalities to college education will be developed in which migration is introduced into the model. The second section will discuss the empirical model and the third section will discuss the estimation and the results. Finally, some brief conclusions will be made.

\section{Externalities to Education and Wage Rates}

The possible existence of external benefits to education has long been thought to exist. The standard economic justification for public funding of education depends upon the argument that there are external benefits to education (Schultz, 1988). The existence 
of external benefits implies that without public support, society would under invest in education. External benefits also imply that it would be unfair for individuals to pay for their entire education because they would be paying for benefits they do not receive. Confirming the existence and measuring the magnitude of these external benefits is essential if we are to provide the optimal subsidy for economic efficiency.

For the most part the literature on college education has focused on private returns. Attaining a college degree is seen to be an investment in human capital. The cost of this investment is foregone earnings from delaying entry into the labor market plus net tuition and other direct costs of attending college. The return is the present value of higher wage rates that college graduates earn. Following Mincer (1974) there have been various estimates of the wage premium from a college degree that find this premium to be substantial, particularly in the US.

Much of the literature on the external benefits of education has focused on education in general. Early examples of this literature are Marshall (1890), Weisbrod (1962), and Friedman (1962). Marshall emphasized the informal sharing of skills among workers. Weisbrod emphasized a number of economic and non-economic externalities including the creation of a better learning environment for one's own children and in one's community. Friedman mentioned the impact of a better educated electorate in making decisions leading to better public choices affecting the economy.

Lucas (1988) introduced these externalities to education into a growth model. He argued that these externalities are essential if we are to explain international differences in income. Lucas considers a Cobb-Douglas production function

(1) $Q=A K^{\alpha} L^{1-\alpha}$, 
where $L=\lambda(E) N$, where $\lambda(E)$ is worker productivity, $E$ is education, $N$ is the size of the labor force, $\mathrm{K}$ is total capital, $\mathrm{Q}$ is total output and A represents technology and other influences on total factor productivity. Externalities to education are introduced by making $A=A(E)$, i.e., the productivity of all factors are a positive function of education. Lucas considers several examples to make his argument. He takes an example where there is a substantial difference in income between a rich and a poor countries. This difference might be the result of differences in factor proportions, technology, the internal returns to education and the external returns to education. After considering the realism of these implied factor returns, Lucas concludes that any reasonable explanation of factor returns must rest on the existence of external benefits to education.

One way of testing the Lucas hypothesis is to assume that education will impact wage rates through two channels. First, education increases the productivity of workers directly by increasing $\lambda(E)$. Hence, it will increase that person's productivity and consequently that person's earnings. Second, since Lucas argues that $A$ also depends on the average level of education. Workers with more education may, through example or other spill over effects, increase the productivity of other workers. This externality makes both capital and labor more productive. An externality is an uncompensated impact of one person's action on the well-being of someone else. The externality to education means that an increase in a person's education will have two impacts. First, it will increase that person's productivity which will be reflected in that person's wage rate. Second, it will also increase average level of skill/education and, hence, will increase the productivity of others, which will be reflected in the average wage rate of others. Hence, the returns to capital, labor and education will be higher in regions with higher average education than would be expected in the standard model.

Education affects wage rates by increasing the marginal product of labor (MPL). MPL can be found by differentiating equation (1) with respect to $N$ yielding

(2) $\quad M P L=(1-\alpha)(Q / N)$. 
On the assumption that workers are paid their marginal product, a wage equation can be estimated by substituting the wage rate for the marginal product of labor. Since Lucas was concerned with an aggregate production function and explaining national differences in factor returns, the externalities to education were assumed to be country wide. However, many tests of the Lucas hypothesis are based on the notion that the external benefits were to be observed chiefly within an industry. Winter-Ebmer (1992) and Sakellariou and Maysami (2004) estimate average, industry-specific wage rates based upon the average level of education of workers by industry after accounting for differences in the compensation of workers in the industry. Moretti (2004b) examines spillovers from education within a plant.

A second group of tests assumes that the external benefits to education were spread across a community, which is defined as a metropolitan area. In an early study Rauch (1993) looks at wage rates in US metropolitan areas. Wages are estimated based on the average level of education within the region plus other regional characteristics and the characteristics of individuals within the region. A difficulty with this approach is that an important variable in any wage equation for a region is capital per worker in the region. Since the marginal product of labor is typically thought to be positively related to capital per worker, a key potential source of heterogeneity in a region is not included. Hence, capital per worker is assumed to be endogenous as would be the case in a hedonic migration model (see Roback, 1982 and 1988; and Shields, 1995). Within this context, Rauch found support for the existence of city wide external benefits to education.

Hedonic models are based on an equilibrium assumption where, in equilibrium, the value of regional amenities is capitalized into lower wage rates and the rental price of housing. For the aggregate production function of the form considered by Lucas, in equation (1), land does not enter the production function. Hence, rental costs of land do 
not enter the firm's decision to locate in a given region. Only the wage rate and the productivity of workers enter this decision.

The model is illustrated in Figure 1. Here, workers face a tradeoff between wage rates and housing rental costs. The wage rate, in this example, is to be interpreted as the cost per unit of $L$ and not $N$. The supply of labor is given by $S$ and is upward sloping because workers will tradeoff higher wages for higher rental costs. Workers will move to a region if for a given housing cost, $h$, the wage rate, $w$, is above the supply curve. Hence, the supply of labor is upward sloping reflecting this trade off.

Figure 1.

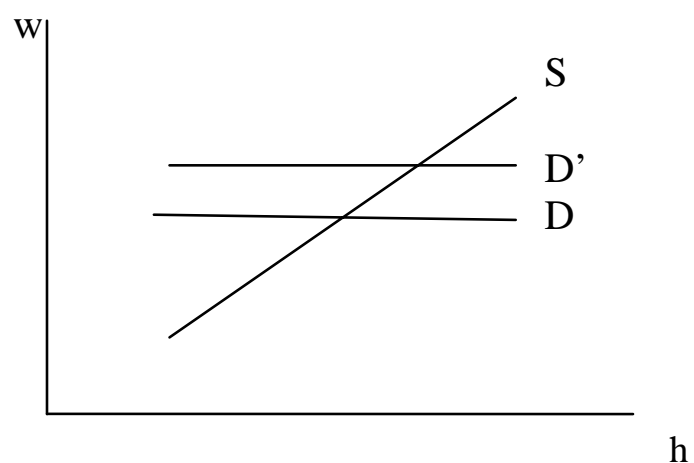

The demand for labor does not depend upon housing costs because in our model land is not a factor of production. Consequently, the demand for labor, $D$, is horizontal. While this assumption comes directly from the production function used, it also makes discussion easier. The results will be similar if $D$ is allowed to be downward sloping. The demand for labor depends on two factors. First, demand depends on the national wage rate. Second, demand depends on productivity within the region. In particular, $D$ will shift upward if external benefits of education make workers and capital more productive. Capital will move to the region until the wage rate rises to the new demand for labor. 
Equilibrium exists in this model when supply equals demand. In a hedonic migration model, regional economies are assumed to be in equilibrium. Capital and labor are distributed between the regions in an optimal manner. Labor receives the same wage rate in every region but pays higher housing costs in regions that have an abundance of consumption amenities. The wage rate of individual workers will depend upon their education and, as we will see, the average level of education in the region.

An increase in the average level of education will increase the marginal product of all workers and, hence, will increase the wage rate. This will shift the demand curve for labor upwards to $D^{\prime}$ in Figure 1. Consequently, the wage rate for each unit of L will rise along with housing prices in regions with an increase in the average level of education. Note that, since capital adjusts to the wage rate, $K / L$ will be the same in every region making it unnecessary to measure capital stock in order to estimate a regional wage equation. We will see that this implication of the model can be tested if we have capital data.

Moretti (2004a) and also uses data for metropolitan areas. Unlike Rauch, Moretti studies college graduates instead of education in general. He extends Rauch's model by using panel data methods and introducing instruments for the supply and the demand for college graduates. He uses a demographic variable as an instrument for the supply of college graduates on the assumption that younger workers are the most likely to have graduated from college and whether the city has a land grant college as an instrument for the demand for college graduates on the assumption that land grant colleges are an exogenous source of technology that is biased toward highly educated workers. Since 
capital data are not available by region, he can not, however, test the appropriateness of the hedonic model.

A few studies have used state-wide data. State wide instruments were used by Acemoglu and Angrist (1999). They use compulsory schooling laws. While they are using state wide data they do not use physical capital, which becomes an unobserved determinant of wage rates. Consequently, they too do not test the appropriateness of the model. Shields and Shields (2006) also use state-wide. For years of education, they find that capital per worker is significant but small. However, it is unclear whether this result is enough to reject the hedonic model because of the small sample size they selected and because they use years of schooling and not college graduation as the education variables.

\section{Empirical Model}

There are two key elements to the empirical model of the returns to college education, both external and internal, that will be developed. The first element is that external returns should be clearly distinguished from internal returns. The second element is that the impact of capital intensity on the wage rate be stated in a testable form. Both can be accomplished by taking the natural logs of equation 2 and collecting terms. The log of the wage rate can then be substituted for the log of the marginal product of labor. The resulting equation, in stochastic form, is then

$$
\begin{aligned}
& \ln \left(W_{S I}\right)=\beta_{0}+\beta_{1} \ln \left(E_{S}\right)+\beta_{2} \ln \left(K_{S} / N_{S}\right) \\
& \quad+\beta_{3} \ln \left(E_{S i}\right)+\beta_{4} \ln \left(X_{S i}\right)+\varepsilon_{S i} .
\end{aligned}
$$

The subscripts, $S$ and ì represent states and individuals. Hence, $W_{S i}$ is the wage rate of individual $i$ living in state $S, E_{S}$ is the proportion of the labor force with a college degree in state $S,\left(\mathrm{~K}_{\mathrm{S}} / \mathrm{N}_{\mathrm{s}}\right)$ is capital per worker in state $S, E_{S i}$ is a dummy variable for whether individual $i$ living in state $S$ 
has graduated from college, $\mathrm{X}_{\mathrm{Si}}$ is a vector of other characteristics of individuals such as experience and gender and $\varepsilon_{S i}$ is a stochastic error term.

The two regional variables, capital per capita and the proportion of the labor force with a college degree, are taken from a Solow growth model as augmented by Lucas. Without migration, a higher capital-labor ratio will increase the marginal product of labor increasing the wage rate but will lower the profit rate. Migration and capital mobility modify this picture. Recall that with migration and capital mobility an increase in the proportion of the labor force with college degrees might increase the wage rate and housing costs. The capital-labor ratio will adjust and, hence, will not be an exogenous variable. If education creates external benefits, a higher average education will increase the marginal product of labor and capital. Hence, higher average education will increase both the profit rate and the wage rate. Furthermore, this increase in labor productivity would occur for all workers. The individual variables will affect the productivity of individual workers and, hence, will also increase the wage rate. Education increases individual human capital and, hence, the wage rate. Consistent with Lucas, only education is assumed to generate external benefits. To estimate the returns to college education, the education variable for the state will be the proportion of the working age population over twenty-five with a college diploma, while the individual education variable will be whether or not the person has completed college. Once the internal and external returns to a college education are estimated, the results can be used and extended to address the questions raised along with various other policy issues.

\section{Empirical Results}

The data come from the two different types of sources. The data on individuals comes from the Current Population Survey. The survey was provided by the Minnesota 
Population Center (IPUMS). To be in the sample the person must be currently employed, have earned income during the past year and be of working age. Data for states come from Geographic Area Statistics: the Annual Survey of Manufacturers and from the Statistical Abstract of the United States. Specific variables used are capital/(labor force), the proportion of the working age population 25 years and older, the age of the individual and various dummy variables represent whether the individual was white, foreign born or male. The proportion of the labor force that has graduated from college was calculated for each state using the micro data provided by IPUMS.

As explained earlier, they variables of most interest are the two college education variable and the capital variable. A dummy variable will be used for whether a person has graduated from college and the percentage of college graduates in the state will be used to capture the external effects of education. It is expected that both variables will have a positive impact on wage earnings. The other statewide variable, capital/(labor force) is expected to be positive but could be insignificant. Its insignificance would lend support to the hedonic migration model. The age of the worker is used to capture human capital that increases with experience. The other variables are dummy variables indicating whether a worker is white, native born or male. These dummy variables are all expected to have a positive impact on the wage rate, partly because of differences in acquired human capital but also partly because of economic discrimination.

Four different models are estimated. First, a basic model is estimated based on the log-linear production function in equation 1. The results are shown in columns A and B of Table 1. Column A shows the estimates of the basic model discussed above. Next, the basic model is extended by adding some dummy variables for occupation to the basic 
model as a check on the robustness of the results. The results are shown in column B. Finally, for comparison and discussion, estimates for a linear version of the model are shown in columns A (the basic model) and B (the extended model).

The results in all four models show strong support for the existence of external returns to college education. The coefficient, \% College, is significant at the $1 \%$ level. Subsidizing college education or attracting college graduates from elsewhere will substantially increase the average wage rate of all workers. An estimate of the magnitude of this external effect can be most easily seen by looking at the linear models. Here, an increase of one percentage point in the percent of the state's work force that has graduated from college will increase the wage income of all workers by a little more than $\$ 500$ for all workers in both linear models. ${ }^{1}$ However, there is little evidence that a subsidy to capital formation will have any impact on average wage rates. The coefficients in both models are small and insignificant. The results provide support to hedonic migration models where capital flows to a region is the equilibrating factor. Capital seeks out lower wage rates bringing average wage rates up to the national average given education externalities and regional amenities. This result lends support to previous studies that did not use capital data for the US.

Other variables of passing interest are the age, race, birth-place and gender variables. The results for these variables are not surprising. Wage rates tend to rise with age. Older workers are more experienced and hence are more productive. Native born workers earn more perhaps because of discrimination and perhaps because their human capital is better suited to their environment. Women, as expected, earn less than men.

\footnotetext{
${ }^{1}$ Another way of stating the size of this external benefit is that it increases all factor returns by about $1.58 \%$.
} 
There is mixed evidence that whites earn more. Whites earn significantly more in the linear model but not in the log-linear model. ${ }^{2}$

The results suggest a very large optimal subsidy to college education. For simplicity of exposition, consider the linear model. The estimated coefficient for \% College represents the marginal external returns of a college graduate per worker. These returns will occur for every year. Furthermore, the externality will be realized by both employed persons and persons who decide to specialize in household production. The value of the external benefits will be at least as large as the foregone earnings if a person is to withdraw from the labor market. However, these implicit returns will be ignored in the present analysis and only explicit returns will be considered partly because state and federal taxes are not levied on implicit returns.

Since these returns occur through every year of a person's working lifetime, we will need to discount these returns to find the net present value to the state of a college degree. Assuming a 40 year work life and a real discount rate of 3\%, the net present value of $\$ 462$ is $\$ 15,400$. In addition, capital also becomes more productive. The external benefit to capital will be assumed to be one-half the benefits to labor. The reason for this assumption is that historically capital's share of the output is about $1 / 3$ while labor's share is about $2 / 3 .^{3}$ Consequently, the total net present value of this externality, to labor and capital, would be at least $\$ 23,100$. This value exceeds the average four year tuition subsidy in 2000. Hence, the results indicate that the state funding of instructional costs is below the optimum.

\footnotetext{
${ }^{2}$ However, if the native born variable is excluded (in results not shown here), race is significant in both models.

${ }^{3}$ See Mankiw, Romer and Weil (1992).
} 
There are numerous reasons for caution in interpreting this sizeable externality. These reasons are of two types. First, for numerous reasons the estimated coefficient for $\%$ College may be too large. There may be omitted variables, collinear with \% College, that may be important in explaining average labor productivity and, hence, wage rates. These omitted variables could represent other features of state policy. Second, the interpretation of the estimated coefficient may be misleading. In particular, a standard production function suggests nonlinearity. The higher \% College the lower its impact on wages. In order to see which states would have the highest marginal return to investment in college education, refer to Table 2, which shows the percentage of college graduates variable by state for each of the census years. There is considerable variability by state with West Virginia and Indiana having the lower percentage of college graduates. An increase in college subsidies would therefore be expected to have a greater beneficial effect for states like West Virginia and Indiana than for states like Connecticut and Colorado with a more educated population.

A factor that may reduce the external benefits to states from investing in college education is that other states may free ride on their investment by attracting college graduates from other states. The net amount of free riding would be the cumulative net loss in college graduates over the last forty years. Merely establishing that a high proportion of a state's work force that has graduated from college comes from migrants from other states is not sufficient to establish sizeable free riding. Free riding, no matter how extensive, does not provide a basis for arguing that public financing of education should be smaller. It merely provides a basis for arguing that the federal government should provide a commensurate share of this financing. 


\section{Conclusions}

There are sizeable externalities generated by college education for states. The average value of these externalities is suboptimal for the US as a whole. However, individual states might free ride by attracting college graduates from other states. An avenue for future research is to judge the extent to which free riding occurs and, consequently, how much the federal government should pay in support of higher education. Since it is also possible for the US, as a whole, to free ride on other countries investment in higher education, future research could also focus on immigration versus trade policy in terms of their impact on the external benefits from higher education. Freer immigration might be preferable to freer trade, particularly the outsourcing of high skilled production, because it generated these positive externalities from education.

A more complete study would consider a panel beginning in 1994, when state capital variables became available and would introduce instruments into the model, which might be a supply or demand instrument. A possible supply instrument is the proportion of young workers in the labor force. Young workers are more likely to have a college degree than older workers and will increase the supply of college graduates. A possible demand instrument is the number of top research industries in the state. Research industries may increase the relative productivity of college graduates versus other workers within a state and, consequently, increase the demand for college graduates and hence their wage rates. 


\section{Table 1}

\begin{tabular}{|l|l|l|l|l|}
\hline Variable Name & $\begin{array}{l}\text { Model A } \\
\text { Log-linear }\end{array}$ & $\begin{array}{l}\text { Model B } \\
\text { Log-linear }\end{array}$ & $\begin{array}{l}\text { Model C } \\
\text { Linear }\end{array}$ & $\begin{array}{l}\text { Model D } \\
\text { Linear }\end{array}$ \\
\hline Intercept & 5.101 & 5.225 & $-21,022.9$ & -19615.0 \\
& $(46.83)$ & $(43.10)$ & $(-19.44)$ & $(19.40)$ \\
\hline Capital per & 0.005 & 0.006 & -0.301 & -0.098 \\
Worker & $(0.71)$ & $(0.84)$ & $(-1.12)$ & $(0.37)$ \\
\hline \% College & 0.335 & 0.319 & 491.70 & 462.55 \\
& $(14.04)^{* *}$ & $(13.60)^{* *}$ & $(15.95)^{* *}$ & $(15.26)^{* *}$ \\
\hline College Grad & 0.588 & 0.442 & $22,693.55$ & $17,391.58$ \\
& $(71.60)^{* *}$ & $(49.50)^{* *}$ & $(86.56)^{* *}$ & $(61.01)^{* *}$ \\
\hline Age & 0.887 & 0.857 & 541.70 & 519.35 \\
& $(77.22)^{* *}$ & $(75.69)^{* *}$ & $(53.81)^{* *}$ & $(52.39)^{* *}$ \\
\hline White & 0.010 & -0.010 & $1,576.26$ & $1,016.93$ \\
& $(0.95)$ & $(-0.98)$ & $(4.64)^{* *}$ & $(3.04)^{*}$ \\
\hline Native Born & 0.196 & 0.150 & $5,824.24$ & $4,039.67$ \\
& $(18.96)^{* *}$ & $(14.57)^{* *}$ & $(17.58)^{* *}$ & $(12.30)^{* *}$ \\
\hline Male & 0.492 & 0.523 & $15,256.28$ & $17,256.63$ \\
& $(67.74)^{* *}$ & $(68.23)^{* *}$ & $(65.60)^{* *}$ & $(70.38)^{* *}$ \\
\hline Managerial & & 0.265 & & $7,807.39$ \\
Professional & & $(4.71)^{* *}$ & & $(4.34)^{* *}$ \\
\hline Service & & -0.158 & & -4157.23 \\
& & $(-2.79)^{*}$ & & $(-2.30)^{*}$ \\
\hline Sales Office & & -0.010 & & -2862.52 \\
& & $(-0.17)$ & & $(1.57)$ \\
\hline Farming, & & 0.084 & & -2545.97 \\
Fishing, Forestry & & $(1.11)$ & & $(-1.05)$ \\
\hline Transportation & & 0.11 & -3790.1 \\
& & $(0.20)$ & & $(-2.09)^{*}$ \\
\hline \# Observations & 56,594 & 56,594 & 56,594 & 56,594 \\
Adj. R-Square & 0.241 & 0.255 & 0.229 & 0.255 \\
& & & & \\
\hline
\end{tabular}

t-statistics are in parentheses.

*Significant at the 5\% level.

**Significant at the $1 \%$ level. 
Table 2

\section{The percentage of the labor force with a college degree}

\begin{tabular}{|c|c|c|c|}
\hline states & year2000 & year1990 & year 1980 \\
\hline Alabama & 20.4 & 15.7 & 12 \\
\hline Alaska & 28.1 & 23.0 & 21.47 \\
\hline Arizona & 24.6 & 20.3 & 17.67 \\
\hline Arkansas & 18.4 & 13.3 & 10.72 \\
\hline California & 27.5 & 23.4 & 19.74 \\
\hline Colorado & 34.6 & 27.0 & 22.89 \\
\hline Connecticut & 31.6 & 27.2 & 20.98 \\
\hline Delaware & 24.0 & 21.4 & 17.19 \\
\hline District of Columbia & 38.3 & 33.3 & 28.62 \\
\hline Florida & 22.8 & 18.3 & 14.96 \\
\hline Georgia & 23.1 & 19.3 & 14.52 \\
\hline Hawaii & 26.3 & 22.9 & 19.76 \\
\hline Idaho & 20.0 & 17.7 & 15.51 \\
\hline Illinois & 27.1 & 21.0 & 15.93 \\
\hline Indiana & 17.1 & 15.6 & 12.16 \\
\hline lowa & 25.5 & 16.9 & 14.28 \\
\hline Kansas & 27.3 & 21.1 & 17.72 \\
\hline Kentucky & 20.5 & 13.6 & 11.36 \\
\hline Louisiana & 22.5 & 16.1 & 13.65 \\
\hline Maine & 24.1 & 18.8 & 14.33 \\
\hline Maryland & 32.3 & 26.5 & 20.88 \\
\hline Massachusetts & 32.7 & 27.2 & 20.5 \\
\hline Michigan & 23.0 & 17.4 & 14.39 \\
\hline Minnesota & 31.2 & 21.8 & 17.82 \\
\hline Mississippi & 18.7 & 14.7 & 12.4 \\
\hline Missouri & 26.2 & 17.8 & 13.81 \\
\hline Montana & 23.8 & 19.8 & 16.68 \\
\hline Nebraska & 24.6 & 18.9 & 14.06 \\
\hline Nevada & 19.3 & 15.3 & 14.86 \\
\hline New Hampshire & 30.1 & 24.4 & 17.65 \\
\hline New Jersey & 30.1 & 24.9 & 18.19 \\
\hline New Mexico & 23.6 & 20.4 & 17.8 \\
\hline New York & 28.7 & 23.1 & 17.67 \\
\hline North Carolina & 23.2 & 17.4 & 13.19 \\
\hline North Dakota & 22.6 & 18.1 & 10.91 \\
\hline Ohio & 24.6 & 17.0 & 13.88 \\
\hline Oklahoma & 22.5 & 17.8 & 15.33 \\
\hline Oregon & 27.2 & 20.6 & 18.18 \\
\hline Pennsylvania & 24.3 & 17.9 & 13.73 \\
\hline Rhode Island & 26.4 & 21.3 & 13.95 \\
\hline South Carolina & 19.0 & 16.6 & 13.32 \\
\hline South Dakota & 25.7 & 17.2 & 12.72 \\
\hline Tennessee & 22.0 & 16.0 & 12.61 \\
\hline Texas & 23.9 & 20.3 & 16.86 \\
\hline Utah & 26.4 & 22.3 & 19.94 \\
\hline Vermont & 28.8 & 24.3 & 19 \\
\hline Virginia & 31.9 & 24.5 & 19.61 \\
\hline Washington & 28.6 & 22.9 & 19.34 \\
\hline West Virginia & 15.3 & 12.3 & 10.5 \\
\hline Wisconsin & 23.8 & 17.7 & 14.89 \\
\hline Wyoming & 20.6 & 18.8 & 16.35 \\
\hline US Average & 25.2 & 20.0 & 16.2 \\
\hline
\end{tabular}




\section{References}

Acemoglu, D. and J. Angrist (1999) "How Large are Human-Capital Externalities? Evidence from Compulsory Schooling Laws,” NBER Macroeconomics Annual, 15 pp. 9-59.

Aly, H. and M. P. Shields (1999) "Privatization and Surplus Labor in the Egyptian Textile Industry,” Economics Letters, 63, pp. 187-91.

Friedman, M. (1962) Capitalism and Freedom, Chicago: University of Chicago Press.

Groen, J. A. (2004) "The Effect of College Location on Migration of College-Educated Labor,” Journal of Econometrics 121:125-42.

Hsiao, C. (1986) “Analysis of Panel Data,” Cambridge, UK: Cambridge University Press.

Jeon, Y. and M. P. Shields (2005) "Integration and Utilization of Public Education Resources in Remote and Homogenous Areas: A Case Study of the Upper Peninsula of Michigan,” Contemporary Economic Policy, 23 (October 2005):60114.

Lucas, R. E., Jr. (1988) “On the Mechanics of Economic Development,” Journal of Monetary Economics, 22, pp. 3 - 22.

Mankiw, N. G., D. Romer and D. V. Weil (1992) "A Contribution to the Empirics of Economic Growth,” Quarterly Journal of Economics 107 (May):407-37.

Marshall, A. (1890) Principles of Economics, $8^{\text {th }}$ Edition, (London: Macmillan), 1947.

Mincer, J. (1974) Schooling, Experience and Earnings, NBER, New York.

Moretti, E. (2004a) "Estimating the Social Return to Higher Education: Evidence from Longitudinal and Repeated Cross-sectional Data,” Journal of Econometrics, 121, pp. 175-212.

Moretti, E. (2004b) “Worker’s Education, Spillovers and Productivity: Evidence from Plant-Level Production Functions,” American Economic Review 94(June):656-90.

Roback, J. (1982) "Wages, Rents, and the Quality of Life," Journal of Political Economy 90 (December):1257-78.

Roback, J. (1988) "Wages, Rents, and Amenities: Differences Among Workers and Regions," Economic Inquiry 26 (January):23-41.

Rauch, J. E. (1993) "Productivity Gains from Geographic Concentration of Human Capital: Evidence from the Cities,” Journal of Urban Economics 34 
(November):380-400.

Schultz, T. P. (1988) "Education Investments and Returns," in Handbook of Development Economics, Vol. I, (eds.) H. Chenery and T. N. Srinivasan, Amsterdam: NorthHolland Publishing, Chapter 13, pp. 543-630.

Shields, M. P. (1995) "Time, Hedonic Migration, and Household Production," Journal of Regional Science, (February):117-134.

Shields, M. P. and G. M. Shields (2006) "Estimating External Returns to Education: A Production Function Approach,” Working Paper, Central Michigan University, forthcoming, Applied Economic Letters.

Weisbrod, B. A. (1962) "External Effects of Investment in Education," Journal of Political Economy, 70 (Supplement):106-23

Winter-Ebmer, R. (1992) “Endogenous Growth, Human Capital, and Industry Wages”, CEPR Discussion Papers: 714.

Wooldridge J. M. (2003) Introductory Econometrics, Second Edition, South-Western College Publishing Cincinnati, OH. 